\title{
Autonomous Learning and Principles for Deep Knowledge
}

\author{
I-Chin Nonie Chiang
}

Foreign Language Center, National Chengchi University, Taiwan

Copyright@2018 by authors, all rights reserved. Authors agree that this article remains permanently open access under the terms of the Creative Commons Attribution License 4.0 International License

\begin{abstract}
This study aims to understand whether students have the ability to interpret the connotation of deep knowledge based on afterschool autonomous learning activities, habitual domains and principles for deep knowledge, and to use deep knowledge principles to analyze the relationship between the common autonomous learning activities and knowledge as well as students' rating on various types of deep knowledge. There were 71 participants in this study, and data were collected from group discussions and written records. The results showed that the students have the ability to understand the connotation of deep knowledge and propose a variety of autonomous learning methods. This study explored how these autonomous learning methods are closely connected to the deep knowledge of habitual domains based on the methods proposed by the students. The author also gave teaching suggestions in accordance with the participants' rating on the deep knowledge.
\end{abstract}

Keywords Autonomous Learning, EFL, Habitual Domains, Principles for Deep Knowledge

\section{Introduction}

After promoting English education for decades, Taiwan has started to advocate autonomous learning in recent years, hoping to cultivate the concept of lifelong learning. In the course of designing innovative curriculum for college English, autonomous learning has also become one of the goals of many universities in Taiwan. In general, under Taiwan's education system, learning is passive. How to change students' attitude and behavior is the key to turn passive learning into active learning. Therefore, this article first elaborates the theory of autonomous learning and deep knowledge of habitual domains, and moves on to explore the relationship between autonomous learning and deep knowledge. That is, how to interpret autonomous learning activities via deep knowledge principles.

\section{Literature Review}

\subsection{Autonomous Learning}

First, there are different definitions of autonomous learning, such as Benson and Holec [1, 2]. However, simply stated, autonomous learning is "conscious, active and enthusiastic learning" [3]. In the field of English learning, most scholars believe that a large number of appropriate language input is necessary for language improvement. Since Taiwanese students are used to taking in knowledge passively because of the relatively passive system, many teachers have decided to put more effort in promoting autonomous learning after the success of flipped classroom. For example, Chen [4] designed autonomous classroom learning activities and surveyed students' thoughts on the curriculum with a questionnaire. She found that students still preferred activities taught by teachers, and did not particularly support time-consuming afterschool activities (e.g., researching for a specific topic after class). "Watching videos, TV series or movies of relevant topics" were the most popular activity, and "reading articles on related topics" was the activity that was most effective in enhancing the English ability.

Nation [5] pointed out that the biggest problem of English as Foreign Language (EFL) is that there is no adequate and appropriate target language input for EFL learners. Classroom learning is insufficient to maximize language exposure in Taiwan. Therefore, it is necessary to enhance afterschool language. The article will focus on extracurricular autonomous learning activities rather than autonomous teaching activities in class. Thanks to the advancement of technology, diversified lifestyle and higher quality of life, students can be immersed in a variety of extracurricular language activities and no longer solely rely on books and magazines. Regardless of the interface, the more the students are exposed to the target language, the better the students' achievement in the target language is. Take the studies regarding print exposure for example, print exposure is shown to significantly predict 
language learning achievement [6]; in addition, Mol and Bus [7] concluded that print exposure can enhance language and reading ability and can lead to a larger amount of reading, after their extensive review on 99 relevant studies. Most of my previous studies focused on extracurricular reading with a purpose to promote language exposure outside of the classroom. Therefore, I have also been very interested in students' autonomous learning in other extracurricular activities. I helped organize a series of lectures on autonomous learning in the school I work in the second semester of 2016. The lectures included how to use apps to learn English within a short time period, how to use the video resources or various platforms online to learn English, and how to help students succeed in autonomous learning through teaching. Experts in learning English were also invited to share their experiences in successful learning. The students enthusiastically participated in the lectures and discussed with the lecturers. The lectures were highly praised, indicating that the students were very interested in autonomous learning. However, based on my teaching experience, observation and studies, there is still a lot of room for college students in Taiwan to improve their extracurricular English exposure. For instance, less than half of the students were willing to participate in afterschool English study groups, and the students were not interested in regular weekly reading [8]. Therefore, after observing the contradiction between the students' wish to master autonomous learning and their failure to take action, I want to explore this issue with habitual domains and principles of deep knowledge.

\subsection{Habitual Domains (HD) and Principles for Deep Knowledge (PDK)}

According to the habitual domains theory,

Our memory, concepts, ideas, practices, judgments, reactions (collectively referred to as ideas and operators) are dynamic, but they will gradually stabilize and stayed in a fixed range after some time. The scope of the ideas and operators, including their dynamics and organization are our "habitual domains" [9, p.86].

"Circuit patterns" is the core of the habitual domains and will be strengthened or weakened by the frequency of use [9]. Circuit patterns may be congenital or acquired. For example, basic biological needs are mostly congenital and the acquired circuit patterns are "acquired through experience, imagination and learning" [9, p.81]. In other words, training can strengthen or activate the acquired circuit patterns. Yu [9] summarized situations that are likely to strengthen the circuit patterns: (1) Circuit patterns learned from childhood: Children can be more focused because the number of circuit patterns is smaller; (2) Circuit patterns learned from multiple sources: More channels means more repetition, and thus the corresponding pattern becomes stronger; (3) Circuit patterns generated from high pressure: Patterns are stronger because of increased focus; (4) Circuit patterns used repeatedly: Practice makes perfect; (5) Circuit patterns related to oneself: Special focus and pressure strengthens the patterns when it is self-related and personal; (6) Circuit patterns acquired when one is focused: As long as one is focused, the corresponding pattern will be strengthened even without high pressure; (7) Circuit patterns acquired outside of familiar habitual domains: While facing challenging problems, one is stressed to face his/her own curiosity, so the circuit patterns will be strengthened because of the enhanced focus and concentration [9, p.83-85].

The habitual domains use four concepts to interpret one person's potential [9, p.95]:

1. Potential Domain: All possible ideas and thoughts in our mind or the sum of all circuit patterns.

2. Actual Domain: The ideas and operators that occupy our attention at a particular moment.

3. Activation Probability: This means the chance of a certain idea that catches our attention. The Actual Probability of each circuit pattern is not equal.

4. Reachable Domain: Ideas and operators extended from the Actual Domain are the reachable domains.

Chiang [10] used language learning as an example to explain the four concepts. Our brain is born with a language learning mechanism that can handle unlimited syntax. This is the Potential Domain. Talking is the behavior that reflects our brain's current attention; that is the Actual Domain. The progress we make after we find our grammatical errors or after we are corrected is the Reachable Domain. Finally, the Activation Probability can be used to explain that certain syntax is easier to access and master (e.g., present continuous tense) while others are more difficult (e.g., subject-verb agreement and tense). These four concepts are dynamic and may change in accordance with the context. This also explains why we still make syntactic errors we have mastered for a long time in the course of language learning. For example, the third person singular in the simple present tense should always end in $-\mathrm{s}$, yet learners sometimes forget, or "he" and "she" are often mixed in a conversation, causing confusion and misunderstanding to the listeners. 
Table 1. Basic concepts of PDK

\begin{tabular}{|c|c|}
\hline PDK & Basic concept \\
\hline $\begin{array}{l}\text { 1. Deep and down } \\
\text { Principle }\end{array}$ & $\begin{array}{l}\text { This principle has two meanings: (1) Put down desire and reduce stress: when the stress is high, only strong and powerful } \\
\text { circuit patterns (ideas and operators) get our attention. If we can reduce stress, weaker circuit patterns may be noticed; (2) } \\
\text { Humble attitude: If we are humble, we can appreciate more and have better views to enlarge and enrich the habitual } \\
\text { domains. }\end{array}$ \\
\hline 2. Alternative Principle & $\begin{array}{l}\text { Sometimes, we need to remove, replace or combine the relevant assumptions, prerequisites or possible consequences so } \\
\text { that we can generate a variety of assumptions and views. }\end{array}$ \\
\hline $\begin{array}{l}\text { 3. Contrasting and } \\
\text { Complementing } \\
\text { Principle }\end{array}$ & $\begin{array}{l}\text { Like a coin has two sides and the balance of Yin and Yang, when we consider two contrasting characteristics and their } \\
\text { complementing characteristics, we can open our mind (habitual domains) and embrace new or original ideas. }\end{array}$ \\
\hline $\begin{array}{l}\text { 4. Revolving and } \\
\text { Cycling Principle }\end{array}$ & $\begin{array}{l}\text { Everything follows the law of nature: born } \rightarrow \text { grow } \rightarrow \text { mature } \rightarrow \text { die } \rightarrow \text { return to nature. All creatures follow this path: born, } \\
\text { grow, mature, die and return to nature. This is the revolving and cycling of an organism. }\end{array}$ \\
\hline $\begin{array}{l}\text { 5. Inner Connection } \\
\text { Principle }\end{array}$ & $\begin{array}{l}\text { Put oneself in someone else's shoes. To understand or influence a person, we need to know the core of the habitual domain } \\
\text { of others or ourselves and establish many strong and powerful channels of connection; the more, the better. }\end{array}$ \\
\hline $\begin{array}{l}\text { 6. Changing and } \\
\text { Transforming Principle }\end{array}$ & $\begin{array}{l}\text { At extreme, one thing changes to another. When the relevant parameters of something reach extreme, they transform or } \\
\text { evolve. }\end{array}$ \\
\hline $\begin{array}{l}\text { 7. Contradiction } \\
\text { Principle }\end{array}$ & $\begin{array}{l}\text { To examine the correctness of a conclusion, we can look at it from an opposite direction and see if we can find } \\
\text { contradictory examples. If we find any contradictory example, we should amend the conclusion to make it more accurate. }\end{array}$ \\
\hline $\begin{array}{l}\text { 8. Cracking and Ripple } \\
\text { Principle }\end{array}$ & $\begin{array}{l}\text { There are various cracks in our habitual domains. Because the habitual domain is composed of many small systems, there } \\
\text { might be inevitable conflicts or inconsistency among the small systems. Such conflicts or inconsistency causes cracks. We } \\
\text { need to keep an eye on the changes in the habitual domains caused by these "cracks and ripples" from time to time. }\end{array}$ \\
\hline 9. Void Principle & $\begin{array}{l}\text { The outside of habitual domain is not void. To allow the habitual domain to continue to expand endlessly, we need to void } \\
\text { our habitual domains, and let go of all constraints of thinking so that other people and things in the universe can enter our } \\
\text { mind and get our attention. }\end{array}$ \\
\hline
\end{tabular}

Once the habitual domain is formed, we tend to use our intuition (under the principle of minimum resistance) and rigidly adhere to a certain mode of thinking and behavior. Therefore, how to change behavior, reactivate our ideas and operators, enhance the ability to respond flexibly, get rid of rigid thinking and bring the brain's unlimited potential into full play are abilities everybody should have. As a result, the "nine principles of deep knowledge" was developed to expand the existing habitual domains under the theory of Habitual Domains. The principles of deep knowledge allow us to see our own or others' habitual domains from the "observable actual domains" systemically and efficiently, and understand and handle problems effectively [9, p.62]. The nine principles of deep knowledge are summarized in Table $1[9]^{1}$.

\subsection{Research Tools and Data Collection}

Because of the lack of reference materials for extracurricular English autonomous learning and deep knowledge, I collected the information using survey research. After explaining the objective of the study to the students, I asked the students if they wanted to participate in the study, and the students who were willing to participate signed a consent form to provide information for this study. The students were divided into groups (3 to 5 students in a group and the students can choose their own members), and each group was given 10 to 15 minutes to discuss the following three questions while I recorded the students' feedback.

1 Due to the length of the article, please see the relevant literature for the details of the habitual domains [9, 11-13].
1. Why do you think the following learning traits (one of the nine basic concepts of deep knowledge; take the deep and down principle for example, the prompts include reducing pressure and keeping a humble attitude) can help enhance the motivation of autonomous learning?

2. What are the characteristics of deep knowledge in the autonomous learning activities that the students like?

3. To what extent do the students understand and evaluate each deep knowledge principle?

To prevent the students from being scared away by terminology, I decided to use only the basic concepts of each principle to guide the discussion. Because of the time constraints, each group randomly drew one principle out of the nine to discuss. In this way, the basic spirit of the specific principles was discussed in more depth and all principles can be covered. However, because of the arrangement in the beginning and withdrawal in the midway, three groups discussed the "deep and down principle" and only one group discussed the "cracking and ripple principle".

\section{Results}

In this study, 71 participants were asked to answer three questions. First, based on the students' interpretation of PDK, all the participants were able to specifically understand the connotation of each assigned principle, and apply it to English learning. As for autonomous learning, some of the content provided by the students was less 
relevant or vague and thus was not included. For example, some answers were more of an "idea" (such as practice in life) rather than a "method". With regard to the third question, rating, each group rated and clearly stated the reasons. Overall, most principles were rated 7 or more, and only three principles (Deep and Down Principle, Revolving and Cycling Principle, and Contrasting and
Complementing Principle) were rated 6 or less. However, the Deep and Down Principle had three scores, and the average of the score was 7.4. For reading convenience, the answers to Question 1 and Question 2 were summarized in Table 2 (for similar content, only one representative answer is shown here). Table 3 summarizes the students' rating of each deep knowledge principle from Question 3.

Table 2. Summary of deep knowledge and autonomous learning method

\begin{tabular}{|c|c|c|}
\hline PDK & $\begin{array}{c}\text { Student's interpretation } \\
\text { (Question 1) }\end{array}$ & Autonomous learning method suggested (Question 2) \\
\hline \multirow{4}{*}{$\begin{array}{l}\text { 1. Deep and } \\
\text { Down Principle }\end{array}$} & Reduce stress & Reduce stress \\
\hline & $\begin{array}{l}\text { - Learning is more fun without stress. } \\
\text { Autonomous learning is learning based on interest. It is } \\
\text { not for formal education and students are not forced to } \\
\text { learn. Therefore, it is less stressful and the learning } \\
\text { outcome is better. }\end{array}$ & $\begin{array}{ll}\text { - } & \text { Promote self-learning by encouragement, such as earning } \\
\text { extra points. } \\
\text { - }\end{array}$ \\
\hline & Stay humble & Stay humble \\
\hline & $\begin{array}{l}\text { - Autonomous learning means that learning is relaxing and } \\
\text { can reduce stress, and stay humble can make people more } \\
\text { willing to better themselves and gain a sense of } \\
\text { accomplishment as a result. } \\
\text { We are humble because we know our inadequacy. Thus, } \\
\text { we are willing to acquire knowledge and enrich ourselves. } \\
\text { Know our own inadequacy and willing to make more } \\
\text { efforts to learn. }\end{array}$ & $\begin{array}{l}\text { Travel more, see the world, realize how small we are and } \\
\text { broaden the horizon. } \\
\text { Communicate with people in different fields, and discover } \\
\text { our own inadequacy. } \\
\text { Learn from others' strength. } \\
\text { Learn from great men and their humbleness, e.g., read the } \\
\text { biography of Buddha or Gandhi. } \\
\text { Reflect ourselves every day, e.g., learning condition, and } \\
\text { whether the method is effective. } \\
\text { Never put off until tomorrow what you can do today, and } \\
\text { make plans, e.g., progress as scheduled. }\end{array}$ \\
\hline $\begin{array}{l}\text { 2. Alternative } \\
\text { Principle }\end{array}$ & $\begin{array}{l}\text { If we see English as a subject, learning English may end } \\
\text { up being a boring process and we cannot apply the } \\
\text { knowledge we learned to life. If we turn learning English } \\
\text { into a mean to achieve a goal rather than English outcome, } \\
\text { learning English is not results-oriented and what is learned } \\
\text { becomes useful in life. } \\
\text { The fear of English limits one's own learning. Therefore, } \\
\text { we can see more comprehensively without } \\
\text { pre-assumptions and ideas. }\end{array}$ & $\begin{array}{l}\text { Learn the English lyrics you like. } \\
\text { Watch the English videos you are interested in. } \\
\text { Focus on foreign artists and follow their news/updates. } \\
\text { Travel abroad. } \\
\text { Be more confident in your own English ability. } \\
\text { Make foreign friends and do not fear to chat with } \\
\text { foreigners in English. } \\
\text { Ask someone who has a passion for English. } \\
\text { Overcome the fear of English. }\end{array}$ \\
\hline $\begin{array}{l}\text { 3. Contrasting } \\
\text { and } \\
\text { Complementing } \\
\text { Principle }\end{array}$ & $\begin{array}{l}\text { We have different ideas, opinions and dimensions, and } \\
\text { some are more preferable than others. Therefore, to } \\
\text { support our own preference or to falsify other viewpoints, } \\
\text { we seek endorsement from authorities to strengthen our } \\
\text { own points of view through the process of autonomous } \\
\text { learning. } \\
\text { When the views we are learning conflict with each other } \\
\text { or things are in opposing positions, our curiosity drives us } \\
\text { to use a variety of information, tools and ways to find } \\
\text { answers. This motivates autonomous learning. }\end{array}$ & $\begin{array}{l}\text { Develop a habit of reading. For example, develop different } \\
\text { perspectives through extensive reading. } \\
\text { Learning while playing } \\
\text { - } \text { Find like-minded friends and learn from each other. } \\
\text { Always be skeptical and be curious about everything. } \\
\text { Think about both sides of everything. } \\
\text { Do not easily overrule what you think is wrong. } \\
\text { Look at everything with a scientific attitude. } \\
\text { Do not be too subjective. Instead, listen to various } \\
\text { opinions. } \\
\text { You will not know what will happen in the end unless you } \\
\text { try it. }\end{array}$ \\
\hline $\begin{array}{l}\text { 4. Revolving } \\
\text { and Cycling } \\
\text { Principle }\end{array}$ & $\begin{array}{l}\text { Metaphorically, if spiral spring is the course of English } \\
\text { learning, a loop is a cycle. We can improve our English } \\
\text { through multiple cycles, i.e., be exposed to English. } \\
\text { Familiarity brings us into "the zone" faster. Make good } \\
\text { use of spiral power and build self-accomplishment and } \\
\text { habit. } \\
\text { Overcome difficulties and gain a sense of accomplishment } \\
\text { in the course of revolving and cycling. }\end{array}$ & $\begin{array}{l}\text { Be exposed to English regularly (listen to English songs, } \\
\text { watch the International news, listen to the radio and read } \\
\text { English subtitles and read English novels). } \\
\text { Learning skills are built on successful experiences. } \\
\text { Try more challenging tasks. }\end{array}$ \\
\hline
\end{tabular}




\begin{tabular}{|c|c|c|}
\hline $\begin{array}{l}\text { 5. Inner } \\
\text { Connection } \\
\text { Principle }\end{array}$ & $\begin{array}{l}\text { It is boring to repeat one single event. Alternation can be } \\
\text { more stimulative and can enhance different ability. } \\
\text { Have enough motivation to actively learn foreign } \\
\text { languages and other knowledge because of an interest in } \\
\text { one area. }\end{array}$ & 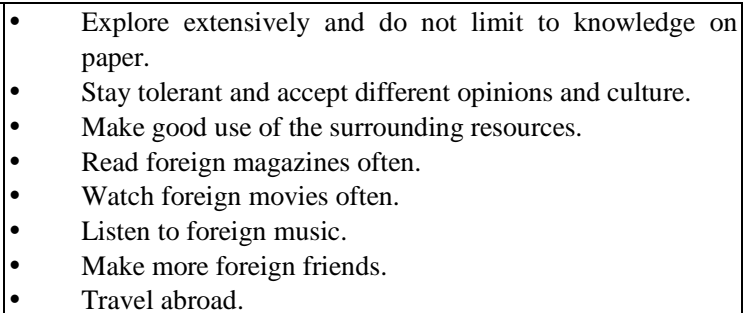 \\
\hline $\begin{array}{l}\text { 6. Changing and } \\
\text { Transforming } \\
\text { Principle }\end{array}$ & $\begin{array}{l}\text { - In the beginning, teachers lead students to learn and read } \\
\text { English. However, the teachers' lead becomes less } \\
\text { necessary once the students read enough and accumulate } \\
\text { enough vocabulary. Their level advances and they can also } \\
\text { gain a sense of accomplishment in other learning } \\
\text { activities. } \\
\text { With this trait, students will find their own way to solve } \\
\text { problems even when they face bottlenecks. Therefore, } \\
\text { they learn actively and achieve the effect of autonomous } \\
\text { reading. }\end{array}$ & $\begin{array}{l}\text { - Set milestones and give a timely reward. } \\
\text { - Make plans and follow the schedule. } \\
\text { - } \\
\text { Eliminate external temptations. } \\
\text { Do not rely too much on others when encountering } \\
\text { problems. } \\
\text { Do not be helicopter parents. } \\
\text { Set a goal to read one new book every week and read the } \\
\text { books with self-motivation. } \\
\text { Do not trust standard answers. Instead, try to think } \\
\text { yourself. }\end{array}$ \\
\hline $\begin{array}{l}\text { 7. Contradiction } \\
\text { Principle }\end{array}$ & $\begin{array}{l}\text { After acquiring the knowledge in the classroom, students } \\
\text { might discover new questions by reverse thinking and will } \\
\text { be motivated to find the answers through autonomous } \\
\text { reading. } \\
\text { In order to apply reverse thinking, the students need to } \\
\text { search for a lot of information to refute the knowledge } \\
\text { gained. They can achieve the purpose of autonomous } \\
\text { learning while looking for counterexamples. }\end{array}$ & $\begin{array}{l}\text { - Stay curious and continue to take in new knowledge. } \\
\text { Be suspicious of things and do not believe and accept } \\
\text { them completely. } \\
\text { Determine the correctness of the information by rational } \\
\text { thinking as well as objective and independent judgment. } \\
\text { Explore new knowledge and develop the new channels. } \\
\text { - Peer discussion and collecting opinions from all parties. } \\
\text { Do not always think in the same way. Instead, try to see } \\
\text { things from different angles when you cannot find the } \\
\text { answer. } \\
\text { Read newspapers and magazines extensively to obtain } \\
\text { different types of thinking from different domains. } \\
\text { Watch others' videos and see others' viewpoints. }\end{array}$ \\
\hline $\begin{array}{l}\text { 8. Cracking and } \\
\text { Ripple Principle }\end{array}$ & $\begin{array}{l}\text { Make good scheduling and reserve a period of time for } \\
\text { enhancing the motivation to learn English autonomously. } \\
\text { However, doing so may cause conflict between the } \\
\text { schedule and other activities. } \\
\text { If students do not understand vocabulary and grammar, } \\
\text { they will misunderstand the context, which in turn reduces } \\
\text { the motivation for autonomous learning. }\end{array}$ & $\begin{array}{ll}\text { - } & \text { Reserve a time slot for reading. A few reading at one time } \\
\text { but read multiple times. } \\
\text { - } \\
\text { - } \quad \text { Fint with short articles that interest you. } \\
\text { Look up wour level. } \\
\text { from the books you read. } \\
\text { - Start with sequels to enhance reading motivation. }\end{array}$ \\
\hline $\begin{array}{l}\text { 9. Void } \\
\text { Principle }\end{array}$ & $\begin{array}{l}\text { - Self-thinking constraint is defined as personal prejudices. } \\
\text { For example, "I cannot do it," "I already know," and "I do } \\
\text { not need to learn" lead to involuntary learning. } \\
\text { People are born with curiosity about new things as well as } \\
\text { desire to know new things. } \\
\text { We are aware of our lack of knowledge in front of new } \\
\text { things. Knowledge is broad and learning is the endless } \\
\text { topic of life. } \\
\text { If we are holding prejudice, we cannot embrace new } \\
\text { things with an open mind. } \\
\text { For example 1. If we are overconfident of our own } \\
\text { language ability and think we do not need to further } \\
\text { improve our ability, we will not think about autonomous } \\
\text { learning. 2. If we confine ourselves to certain fields and } \\
\text { think everything outside the fields is not suitable for us, } \\
\text { we will be less willing to learn. } \\
\text { In addition, compared to the more conservative way of } \\
\text { thinking in the East, the Western thinking style is more } \\
\text { open. If we let go of the constraints on our thinking and } \\
\text { adopt the more open-minded Western style of learning, it } \\
\text { is better for autonomous learning. }\end{array}$ & $\begin{array}{l}\text { - Try new things and do not confine yourself to daily } \\
\text { routine. } \\
\text { Stay curious. } \\
\text { Do not look down on yourself. } \\
\text { Autonomous learning should go from the easy to the } \\
\text { difficult and complicated when it comes to ability } \\
\text { development. } \\
\text { Start with what interests you, and then expand the scope of } \\
\text { autonomous learning. } \\
\text { Replace the original Chinese subtitles with English } \\
\text { subtitles while watching movies. } \\
\text { Read the original version rather than translated version. } \\
\text { Chat with people from different countries. } \\
\text { Try the unfamiliar fields. } \\
\text { Listen to new English songs and watch new English TV } \\
\text { series. } \\
\text { Watch English news. }\end{array}$ \\
\hline
\end{tabular}


Table 3. Students' rating and explanation of PDK (Question 3)

\begin{tabular}{|c|c|c|}
\hline PDK & Score & Explanation \\
\hline $\begin{array}{l}\text { 1. Deep and Down } \\
\text { Principle }\end{array}$ & 9.225 & $\begin{array}{l}\text { - The attitude determines the altitude. One can only discover his/her own inadequacy with a humble attitude, } \\
\text { and improve himself/herself through the progress of science and technology. } \\
\text { We learn a language because we want to satisfy our needs in life and understand the world. A humble } \\
\text { attitude is important, but it is not the most important trait in life. } \\
\text { Being stress-free can make one less motivated, and being humble can help maintain your learning } \\
\text { aspiration. }\end{array}$ \\
\hline 2. Alternative Principle & $\begin{array}{c}8 \\
10\end{array}$ & $\begin{array}{ll}- & \text { Learn English voluntarily and without stress. } \\
\text { - } & \text { This is really important for scientific studies. }\end{array}$ \\
\hline $\begin{array}{l}\text { 3. Contrasting and } \\
\text { Complementing Principle }\end{array}$ & 9 & $\begin{array}{l}\text { - The truth can stand the challenge. Only by continuous introspection can it be clearer. Otherwise, it is } \\
\text { reduced to rigid and dogmatic prejudice. } \\
\text { There are many facets and methods of autonomous learning. Although this characteristic is important, other } \\
\text { characteristics important to autonomous learning should also be considered. }\end{array}$ \\
\hline $\begin{array}{l}\text { 4. Revolving and Cycling } \\
\text { Principle }\end{array}$ & $\begin{array}{l}8 \\
4 \\
\end{array}$ & $\begin{array}{ll}- & \text { This method is great. } \\
\text { - } & \text { The scope is too small and not significant. There are more important elements of autonomous learning. }\end{array}$ \\
\hline $\begin{array}{l}\text { 5. Inner Connection } \\
\text { Principle }\end{array}$ & $\begin{array}{c}8 \\
7.5\end{array}$ & $\begin{array}{l}\text { - With this trait, learning can be maintained and the scope of learning can be expanded. } \\
\text { In this age of rapid information development, we should extensively use other channels to learn the } \\
\text { knowledge we are interested in. }\end{array}$ \\
\hline $\begin{array}{l}\text { 6. Changing and } \\
\text { Transforming Principle }\end{array}$ & $\begin{array}{l}7 \\
9 \\
9\end{array}$ & $\begin{array}{l}\text { - Hours in school are limited but knowledge is unlimited. Once we have the autonomous learning ability, we } \\
\text { can keep learning for a lifetime. } \\
\text { - This is an important key point to motivate autonomous learning. }\end{array}$ \\
\hline 7. Contradiction Principle & $\begin{array}{c}10 \\
9\end{array}$ & $\begin{array}{ll}\text { This is a necessary trait for successful people. } \\
\text { - } & \text { All knowledge begins with refutation. }\end{array}$ \\
\hline $\begin{array}{l}\text { 8. Cracking and Ripple } \\
\text { Principle }\end{array}$ & 8.5 & All small systems need to work together. If not, the learning motivation and outcome are reduced. \\
\hline 9. Void Principle & 8.5 & $\begin{array}{l}\text { - The advance of knowledge is rapid. It is harder and harder to understand new things with existing } \\
\text { knowledge. We need to link knowledge of different domains, even unknown ones. In response to this trend, } \\
\text { learning method is more important than the knowledge learned. } \\
\text { We believe that learning is about constant acceptance of new things. Therefore, it is important to put aside } \\
\text { constraints on our own thought, accept new things and expand our own characteristics. }\end{array}$ \\
\hline
\end{tabular}

\section{Discussion and Conclusions}

First, the students were able to accurately interpret each principle, especially the 'Revolving and Cycling Principle', 'Changing and Transforming Principle', 'Contradiction Principle' and 'Cracking and Ripple Principle', which I thought were more abstract and might be more difficult to understand. However, the students could fully express their views, indicating that these principles could have existed and students are able to apply them with proper guidance. This fits the study result of Chiang [14] that university students have a high degree of deep knowledge potential.

Meanwhile, several activities, such as traveling abroad, using audio and video resources (including videos, songs, broadcasts and news), chatting with foreign friends and reading, were mentioned in different deep knowledge principles. These activities were frequently mentioned, indicating that these activities involve several principles simultaneously and are the strongest circuit patterns of the students. In other words, these activities are part of modern student life. Especially, reading was the autonomous activity that was mentioned in each deep knowledge discussion. As the English teacher for these two classes for one year, I was surprised but happy. I was surprised because when I assigned after-class reading in the class, some students always sighed and said they could not finish the reading assignments, which made me anxious and wonder if I pressurized students too much. On the other hand, I was happy that the importance and value of reading indeed existed in the students' circuit patterns and recognized by the students.

Compared to the above-mentioned activities, I think that reading is obviously less appealing. However, reading is the basis of all knowledge and is the foundation of a high-level thinking ability. Nation is the expert in vocabulary in the English teaching field. In his studies $[18,19]$, he pointed out that, on average, one needs to master $98 \%$ vocabulary, i.e., $2 \%$ new words, to achieve a good level of understanding, and this level is about 9,000 word family. Moreover, based on conservative estimation, to master a word, one needs to repeat and use the word for about 12 times. To achieve such repetition, one needs to have sufficient reading quantity. Based on the above assumption, to achieve the level of 2,000 word families and 12 times of repetition, one needs to read two unsimplified novels of 150 to 200 pages in a year. For a foreign language learner, the average learners' reading speed is about 150-200 words per minute. Based on the learning scenario of five days a week and 40 weeks a year, if a language learner wants to achieve the vocabulary level of 2,000 word family ${ }^{2}$, he/she needs to read at least 33

2 The 1,000 to 3,000 word family is more frequently occurring words and usually learned earlier. The 4,000 to 9,000 world family is a middle-frequency word family. 
minutes a week to achieve 12 times of repetition (if we only consider reading for input). In other words, he/she needs to read at least 7 minutes a day, which is not only possible but also easy to achieve. However, in order to achieve the vocabulary level of 5,000 word family, one needs to read about 10 novels, which is about 33 minutes of reading every day, i.e., about half an hour (possible but relatively difficult). To achieve the vocabulary level of 9,000 word family, one needs to read one hour and 40 minutes (possible but very difficult). Nation also compared reading and input from various sources, such as watching the news, watching movies and reading academic articles, in his study. Based on the statistics of language database, at the 2 million words level, more than 8,000 word families can be found in the journal and novel category. If the language input is limited to the oral input, the vocabulary drops to 6,000 word family because oral use contains less vocabulary but higher repetition. Moreover, novel alone can achieve 8,000 word families. However, novel plus movie can achieve 8,276. Therefore, it is suggested that learners should read magazines, newspaper, novels and watch movies extensively. It seems that the suggestions made by the students about the direction of autonomous learning are generally consistent with the results of the research conducted by experts.

Let us review such autonomous learning method and research results from the viewpoints of PDK. Watching movies not only triggers learning motivation and provides practical and diverse language sources [20] but also reduces the stress brought about by reading (Deep and Down Principle). Therefore, if audio books or videos are available online, I would recommend them to the students, and students can freely choose the language input they prefer. I choose books that are easy to read for students. My standard is set at the B2 to C1 level of the Common European Framework of Reference for Languages, and the length is generally about 25,000 to 30,000 words. I also encourage my students to read teenage novels, such as The Report Card. This practice rebuffs the myth of reading difficult novels. The students can discuss the important topics in the book from simpler content, and participate in the discussion in the class after reading the novels (Alternative Principle). Opposite point of view may raise, and the students will look for authority to endorse their point of view and preference, which in turn results in learning. When the students disagree with the opinion in the books or during the discussion, they can discuss rather than be over-subjective (in opposing position or exchange position). Therefore, discussion after reading is an important activity [5]. Based on the students' ideas, learning abilities are built on successful experience, and the students gain a sense of achievement through challenging tasks. The students compared a spiral to the course of learning. A loop is a cycle, and multiple loops are multiple exposures to English (Revolving and Cycling Principle). Therefore, most of the time, we read from easier content to more difficult ones, but sometimes we go back to read easier books just to enjoy reading [21]. The Inner Connection Principle is to find a suitable method (e.g., listening, speaking, reading and writing skills), use it often and establish a strong and powerful inner channel so that new knowledge and old knowledge can be connected for innovation (Inner Connection Principle). The more the connection is, the stronger the circuit patterns are. Therefore, text, videos, songs and even stage plays of the same topic can be used so that the students can experience different strength levels, and have a stronger impression. Teachers can guide the students to learn English. However, to a certain level, the role the teachers play should be changed to coaches or counselors (Changing and Transforming Principle). When exercising reverse thinking in learning, the students have to spend a lot of time looking for counterexamples. In this process, the objective of autonomous learning can be achieved (Contradiction Principle). Although this process is more time-consuming, it is worthwhile because the students' thinking has been improved. In a broader sense, vocabulary and grammar are the small structure of language composition. Unstable foundation diminishes comprehension, leading to poor learning outcomes (Cracking and Ripple Principle). Thus, it is important to find reading materials suitable for one's own level, as suggested by the students as one of the autonomous learning methods. Difficult articles are hard to read and comprehend, and the students lose interest quickly [21]. Finally, it is hard to accept new things with an open mind if one is holding prejudice. For example, compared to the more conservative Eastern style of thinking, Western style of thinking is more open. If the students can let go of the constraints of existing thinking and adopt a more open-minded Western style of learning, the students can learn more autonomously (Void Principle).

Finally, based on the students' rating, the scores of Contrasting and Complementing Principle and Revolving and Cycling Principle were slightly lower (5 points and 4 points, respectively). However, the students also provided explanations. The two principles are not considered unimportant; instead, relatively speaking, there are more important elements of autonomous learning under these principles. Therefore, in the future, I can elaborate these two principles or develop better examples so that the students can understand the importance of them and I can convince the students to train these two types of knowledge. For example, people tend consider opposite position hostile rather than complementary and important, which leads to argument. When this happens, we should try to ask them to see from a different perspective, and find a different point of view, enhancing their stature to solve the problem. According to the students' opinion, the scope of revolving and cycling principle is too small and thus is not important. Nevertheless, the scope is very big as a matter of fact. Every time the students see the same word, it is one revolving cycle. The brain re-extracts the 
memory, logs the memory, utilizes short-term memory and travels back to long-term memory (cf. [5, 18-19]). Every time we review a concept we forgot, it is a cycle. When we have a pleasant learning experience, we create a positive cycle; otherwise, a negative cycle. This happens all the time and changes all the time so that we have an opportunity for correction.

It is not easy to change the habits right away. However, with a positive feedback mechanism, it is more achievable because the learners can enjoy it. Some teachers believe that teaching is more efficient than autonomous learning. However, in the long term, autonomous learning helps the students to develop good habits that the students can benefit from for a lifetime. The autonomous learning tools and environment provided by the modern society and technology offer the learners more resources. Therefore, to help the students with autonomous learning, the teachers must constantly think about how to use different learning tools and methods and provide students with adequate teaching materials to respond to their needs [4]. In addition, the teachers still need to assist the students in setting milestones and schedule designated reading time. Students often say, "I am so tired. I will read tomorrow." or "there is too much reading. I cannot finish it." If the teacher can guide the students to change their mind so that they can tell themselves that "I will read five minutes today," or "I am tired today, but I will watch English video for relaxation." If the students can keep the habit of doing one thing, I believe the potential domain of the students can be activated very soon, and the students can find a way to change the undesirable habits from the weak circuit patterns.

\section{REFERENCES}

[1] P. Benson. Learner autonomy in the classroom, In D. Nunan (Ed.), Practical English Language Teaching, McGraw Hill, New York, 289-308, 2003.

[2] H. Holec. Autonomy and Foreign Language Learning, Pergamon, Oxford, 1981.

[3] H. Y. Zhou, The Three Elements of Successful Autonomous Learning, Online available from http://www.master-insight.com/?p=29552

[4] C-C. Chen. The Study of University Students' English Learning Attitude and Autonomous Learning, The Proceedings of the $2^{\text {nd }}$ Conference on College English, 97-126, 2008.

[5] P. Nation. Designing reading tasks to maximize vocabulary learning, Applied Research on English Language, Vol.3,
No.1, 1-7, 2013.

[6] S. Y. Chen, The Quest: Print exposure? The Measurement and Importance, Online available from https://www.most.gov.tw/hum/ch/detail?article_uid=1b320 7ef-2e7f-4da5-b1d2-02362eaa8bc7\&menu_id=6203d664-5 2ba-4dc1-8a93-e23b913b875a\&content_type=P\&view_mo de= gridView

[7] S. E. Mol, A. G. Bus. To Read or Not to Read: A Meta-Analysis of Print Exposure from Infancy to Early Adulthood. Psychological Bulletin, Vol.137, No.2, 267-296, 2011.

[8] I. N. Chiang. Extra-curricular reading in Taiwan. Asian EFL Journal Professional Teaching Articles, Vol.80, 4-33, 2014.

[9] P. L. Yu. HD: Habitual Domains, China Times Publishing Co, Taipei, 2009.

[10] I. N. Chiang. The habitual domain, brain research and language learning. Journal of Habitual Domains, Vol.4, No.1, 43-56, 2012.

[11] P. L. Yu. Habitual Domains: Freeing yourself from the limits on your life, Highwater Editions, Kansas, 1995.

[12] P. L. Yu, Habitual Domains - The under-discussed human software, China Times Publishing Co, Taipei, 1998.

[13] P. L. Yu. Habitual domains and forming winning strategies, NCTU Press, Hsin-Chu, Taiwan, 2002.

[14] I. N. Chiang. Principles of deep knowledge and language learning, The proceedings of the $19^{\text {th }}$ annual conference of habitual domains, Habitual Domain Association, 1-9, 2011.

[15] I. N. Chiang. A New Interpretation of English Reading Activities: The Implementation of the Principles of Deep Knowledge, International Journal of Language and Linguistics, Vol.12, No.4, 152-161, 2015.

[16] I. N. Chiang. Reading Habits, Language Learning Achievements and Principles for Deep Knowledge. Linguistics and Literature Studies, Vol.4, No.3, 203-212, 2016.

[17] L. Lin. Habitual Domains and the Learning Achievement: in the Case of the Chinese Courses in University, Journal of Habitual Domains, Vol.5, No.2, 65-83, 2014.

[18] P. Nation. How much input do you need to learn the most frequent 9,000 words? Reading in a Foreign Language, Vol.26, No.2, 1-16, 2014.

[19] P. Nation. Is it Possible to Learn English Vocabulary from Extensive Reading? Online available from https://www.youtube.com/watch?v=GpsVp95Wu_E

[20] S. Stempleski, B. Tomalin. Film, Oxford University Press, Oxford, 2001.

[21] R. Day, J. Bamford. Extensive Reading in the Second Language Classroom. Cambridge University Press, Cambridge, 1998. 